\title{
Gender inequality and economic growth: A methodological divide
}

\author{
Hassan Hussein Ph.D. \\ Assistant Professor \\ College of Saint Benedict and Saint John's University
}

\begin{abstract}
The contribution of small business to the economic growth is statistically prominent in developing economies. Such contribution, that usually dominated by formal entrepreneurs, is praised by governments and international development agencies and easily captured by quantitative queries. Much less visible has been the role of informal entrepreneurs especially underprivileged women working in informal small businesses and their contribution to economic growth remained uncaptured by most quantitative research. This article shed the light on the methodological divide on the often-neglected issues of the contribution of women's informal business to entrepreneurship and national economic growth. It shows how unprivileged women are able to overcome legal, social and administrative barriers that impede women's ability to start a business and participate in monetized economic activities. The article is based on two published quantitative and qualitative studies. The latter conducted by the author in three rural villages in Egypt ${ }^{1}$.
\end{abstract}

Keywords: small business; entrepreneurial learning; gender inequality; economic growth.

\section{Introduction}

Men and women both play substantial, albeit different, economic roles in economic growth of most economies. A growing body of microeconomic and macroeconomic empirical evidence (e.g. Alesina \& Rodrik, 1994; Boserup, Tan \& Toulmin, 2013; Ellis, 2007; Ellis, Manuel \& Blackden, 2005; Seguino, 2000) shows that gender inequality directly and indirectly limits women's contribution to economic growth in developing economies. Although gender inequality as a significant explanatory macroeconomic variable of economic growth was used by most empirical research emanating from the recent interest in assessing women's contribution to economic growth, it has not yet been widely embraced by quantitative research that is virtually devoid of a gendered perspective. Empirical economic research has tendency to limit gender inequality in economic growth to women's unpaid or reproductive family labor and neglect their informal monetized economic activities. Examining women's contribution to economic growth

\footnotetext{
${ }^{1}$ IRB Number: 1610E96081. The IRB: Human Subjects Committee of the University of Minnesota in US determined that the referenced study is exempt from review under federal guidelines 45 CFR Part 46.101(b) category \#2
} 
in developing economies, however, shows methodological divide on the often-neglected issue of the contribution of women's informal business to entrepreneurship, Gross Domestic Products (GDP) and national economic growth (Acs \& Szerb, 2007). While economic growth as defined by Samuelson (1975) represents the increase in the inflation-adjusted market value of the goods and services produced by an economy over time, empirical research tends to use indicators that mainly address the institutional and formal enterprises than others. Such methodology underestimate or neglect that economy is an area of the production, distribution or trade, and consumption of goods and services by different agents including individuals (men and women), businesses, organizations, or governments in a given geographical location (Ciccone \& Jarociński, 2010).

One explanation for the failure of some empirical research to capture women's contribution to small business and accordingly economic growth is the way these types of research tends to assess women's participation in public life of their society. Scholarship in public engagement tends to apply socioeconomic status (SES) — education, income, and classas an explanatory model of behavior to predict and understand public participation. Many studies, including those by Miibrath and Goel (1977) provide empirical evidence on the relationship between class and participation. Other studies, including Wolfinger and Rosenstone (1980) have concluded that education, as a component of SES, is indeed one of the best indicators of public participation. In addition, Downs (1957) argues there is cost of participation that entails the time and effort required by an individual to learn about public in order to make an informed decision. In this vein, Brady, Verba and Schlozman (1995) argue that educated individuals are more likely to possess the intellectual, cognitive, knowledge and skills required to navigate the complexity of the public participation process. Their study concludes that the higher the education level, the lower the participation cost that supports the higher level of participation. While Brady, Verba, and Schlozman's explanatory SES model may help assess people's participation in conventional activities (e.g. formal business), it fails to capture other forms of public participation such as involvement in many informal monetized economic activities and widely neglects other groups who fall outside of the selected variables used to determine participation and economic growth - underprivileged women. This paper, therefore, troubles the notion of SES as indicative of public participation of underprivileged women. The findings of this study show how underprivileged women with low socioeconomic status are involved in 
different informal monetized economic activities in private and public domains in rural Egypt; and how such involvement is yet beyond the capture of most research that applies SES as determinant of public participation.

In order to illuminate the methodological divide in capturing the contribution of underprivileged women to economic growth, this paper utilizes the findings of two research on women's entrepreneurship and public engagement in Egypt. The first is the Survey of Young People in Egypt $\left(\mathrm{SYPE}^{2}\right)$ and the second is a qualitative research on women entrepreneurship in rural Egypt conducted by the authors. While the first is a quantitative research used questionnaire to collect data from more than fifteen thousand young people, the latter is based on a series of qualitative interviews and focus group discussions that were undertaken with 47 illiterate women in three villages in rural Egypt. The women interviewed for this study are part of a larger study of women public participation in Egypt. The findings reveal that underprivileged women spontaneously learn about entrepreneurship from their everyday social interactions and utilize their knowledge and skills to start and run small and micro enterprises that contribute to economic growth and such women's informal monetized economic activities are yet beyond the capture of most quantitative research.

\section{Research context}

In authoritarian contexts such as Egypt, schooling may not play the same role as it does in most democratic societies (Baraka, 2008; Finkel, 2002). The value and weight given to education in authoritarian contexts is downgraded by authoritarian regimes, where "investments in human capital are influenced in important ways by the type of regime in power" (Baum \& Lake, 2003, p. 336). One example is the focus of most authoritative regimes is on the access and enrolment rather than quality and attainment (Sieverding, 2012). Nevertheless, the popularity of using SES and traditional schooling as major underpinning determinants of public participation contributes to the paucity of scholarship on other, less formal types of education and may not

\footnotetext{
2 SYPE is the first of its kind national survey that was conducted in Egypt between $2009-2016$ and covers five major areas, including education and public participation. With the purpose of updating the state of knowledge on youth in Egypt, SYPE was carried out by the Population Council, the Center for the Study of Youth and Political Conflict of the University of Tennessee, and the Central Agency for Public Mobilization and Statistics in Egypt with funding support from the USAID, SIDA, UNDP, UNICEF, UN Women and others (Population Council, 2016).
} 
provide evidence of role that informal learning has in promoting public participation. Informal learning is defined by Livingstone (1999) as "any activity involving the pursuit of understanding, knowledge or skill which occurs outside the curricula of educational institutions" (p. 51).

Another challenge to understanding this topic is the lack of research and diverse methodological stances capable of examining women's public participation in rural Egypt. The limited research available focuses heavily on measuring women's participation in state-organized activities (e.g. small and microenterprise run by government and non-governmental-but formal, organizations) while failing to consider the role that everyday, lived experiences plays in their societies. According to Abu-Lughod (2010), research in the field of women's participation has mostly focused on whether there is a deficit of democracy in the macro-context of the Arab region with little attention given to questions of local communities and how underprivileged women practice citizenship. Additionally, despite the emergence of recent literature on the organizational and civic capacity of groups, the focus of much research on the phenomenon of public participation is rooted in the study of the behavior of discrete individuals. Such research tradition tends to cut individuals off from their social context where their engagement and behavior can better be understood as a part of their networks of social interaction (Mohamed, 2017).

The recent nationwide Survey of Young People in Egypt (SYPE) used quantitative approaches and SES determinants to examine the public participation of 15,000 young people. Relaying on SES determinants, SYPE examined individuals in isolation from the social fabric that connects them to their world. SYPE reported that, in general, public participation is low among Egyptians, with only 3.6\% of the entire population reporting that they ever voted. Young women ages 20 to 25 in rural Egypt, in particular, are underrepresented in public and entrepreneurial activities. Furthermore, SYPE concluded that there is a substantial gender gap in participation of rural women with only $1.5 \%$ of young women participating, as opposed to $13.1 \%$ of young men. In assessing the level of public participation, SYPE measures the extent to which young people in Egypt (both female and male) are active in trying to bring about change in their life more broadly in the following activities: formal employment or business, schooling, participation and affiliation with civil society, volunteering in political institutions, and internet and media use. 
The questionnaire used by SYPE correlates the level of formal education attained and earning. The questionnaire used a group of questions to assess participants' level of education by selecting one of several options of formal and government educational institutions. Some of the questions used to assess participants' level of education include: What is the highest stage of schooling that you have entered? What was the last year you completed in that stage? List the degrees and specializations that you have received, the score/grade you earned in each, and the year when you received it. What is/was your major field of study at your faculty or institute? Obviously, the questionnaire neglects any other form of education (informal and non-formal). In addition, the questionnaire inquires about participants' source of earning to indicate their level of participation in entrepreneurial activities using set of questions include: What is your occupation? What is your sector of employment (government, public enterprise, private, investment / joint venture, foreign, non-profit or non-governmental organization, co-operative)? What is the legal status of the firm you work in? What is the number of employees in your firm including yourself? Do you have a bank account or a post office account? Are you looking for or trying to establish your own business? From where did you get the money to start your current business (own savings, savings from family members, loan from family, bank or commercial institution, loan from private money lender, loan/assistance from government institution, loan/assistance from NGO, donor project, etc., or didn't need money)? Are you a member of any of the following associations (syndicate, co-operatives, business associations, commercial union, others, or none)? Once again, the questionnaire adopted several indicators that assess participant's involvement in formal entrepreneurial activities while neglecting other informal forms of business and economic activities especially those initiated and run by underprivileged rural women as an income generating activity.

In this study I argue that the research methodology may represent an important factor for the blurred reality of the contribution of women's informal small business in the economic growth. I argue that low participation of young women in rural Egypt, as reported by SYPE, aligns with two epistemological challenges to the study of public participation: the focus on SES and its quantitative methodological stances. Furthermore, applying western concepts to assess local participation by these kinds of survey may result in a fact that the outcome of such surveys may go awry. Such concepts (e.g., participation in formal public events, affiliation or volunteering with public institutions) assume that a particular mode of participation makes sense 
or resonates irrespective of context where mistakenly assuming that volunteering, for instance, is universally indicative of public engagement. While using these indicatives may be useful in other contexts, it may not be viable in an authoritarian and highly surveilled space. Such "globalized localism" as argued by de Sousa Santos (2006) contributes to a fact that "local conditions are disintegrated, oppressed, excluded, de-structured, and, eventually, restructured as subordinate inclusion." (p. 397). The reliance of SYPE on SES and using "schooling” and "formal enterprise" as universal marker of public participation in entrepreneurial activities is in a sense projecting what counts as "entrepreneurship" in one setting and assuming it has universal coherence and apply it to assess contribution of underprivileged women in rural Egypt. This study, therefore, troubled SYPE and SES to challenge the quantitative methodological approach usually used to examine contribution of underprivileged rural women in business and economic activities in Egypt.

\section{Methodology}

The broad purpose of this study is to understand how informal small business by underprivileged rural women in developing economies contribute to their economic growth. The paper also shed the light on how such contribution remains invisible and yet beyond the capture of most research. This study delves into everyday activities of those women to examine how underprivileged rural women acquire knowledge and skills to start and sustain successful small business that contribute to their economic growth. 47 underprivileged rural women were targeted for this study. The women interviewed for this study are part of a larger study of women public participation in Egypt. The 47 respondents who feature in this study were selected on the basis that they run their own small-scale informal and unregistered business and the sample thus excludes those female entrepreneurs who run registered formal business.

In order to challenge the quantitative queries, usually used to aggregate the contribution of economic activities to economic growth, I adopt a constructivist approach to collect the data of this paper. From the perspective of constructivism, there is no single valid methodology for investigating and discovering truth, but rather a diversity of useful approaches (Lincoln \& Guba, 1985). Thus, the methodology for this study overlaps with three qualitative research genres to investigate the relationship between social interactions and women's entrepreneurial learning and how that relate to their informal business. While this study was predominantly phenomenological 
in nature as it focuses on the everyday lived experiences of underprivileged women, there was a clear overlap with two other genres, namely ethnography and discourse analysis. This phenomenological qualitative study, therefore, was guided by a naturalistic research paradigm where women actively constructed their own meanings and experience of social interactions and spontaneous learning (Lincoln \& Guba, 1985) and where "meaning arise[s] out of social situations and is handled through interpretive processes" (Cohen, Manion, \& Morrison, 2000, p. 137). The phenomenological approach is conducive to understanding the informal entrepreneurial learning of rural women from their perspective, rather than from the perspective of the researcher. Thus, I employed phenomenological methods that helped the women to reflect on their lived experiences and also provided us with the opportunity to uncover these lived experiences.

Grounded in the naturalistic paradigm, qualitative research, according to Lincoln and Guba (1985), "[represents] a distillation of what we think about the world" and provides us the tools needed to examine the world from the individual's perspective (p. 15). Qualitative research, therefore, was best suited to exploring the ways women in rural areas come to learn about entrepreneurship. The decision to use qualitative research methods was motivated by the notion that reality is best understood by examining the social interactions that take place in the everyday lives of individuals in particular settings.

Qualitative semi-structured in-depth interviews were the primary source of data collection for this study. Other methods were also used to complement the data collection sources, including nonparticipant observation, informal conversation, reflective journals, and document analysis. Most of the interviews lasted approximately 60 minutes, and, in a few cases, I scheduled a follow-up interview.

Several factors were considered in the process of selecting the geographic location for this study and the participants. My selection of Egypt as the location of this research stems from Egypt's rural nature, which is relevant to this study. I chose three rural villages in Fayoum governorate: Hope Village, Dream Village, and Bright Village (villages and participants names are pseudonyms). The rational for selecting the rural Fayoum governorate was because it is one of the most impoverished governorates in Egypt with a high percentage of marginalized women with little access to economic opportunities. Fayoum is located about 100 miles southwest of Cairo, with a total population of 2,111,589 as of January 2017 (State Information Service, 2017). 
Among females in Fayoum, 36.8\% are illiterate (mainly in rural villages of Fayoum) and 38.7\% are between the ages of 15 and 30 (General Authority for Adult Education, 2017).

Finally, the issue of validity addressed in this study was also governed by a constructivist paradigm. Creswell and Miller (2000), hold that validity is an important process that aims to ensure the accuracy of the results in representing realities of participants in a social phenomenon where the credibility of these results stems from the participants' acceptance of them. In alignment with this view, my choice of validity procedures relied on the views of participants of the study, the people who read the study, as well as on my view as the researchers and those of the research team for this study. By design, this study employed tenets of credibility and trustworthiness. In order to ensure credibility in collecting the data for this study, I considered disconfirming evidence and triangulation.

\section{Women's uncaptured contribution}

Women entrepreneurs face paradoxical discrimination. From the one hand, they face legal, social and administrative barriers that impede their ability to start business and participate in monetized economic activities. On the other hand, their role in informal monetized economic activities, that I argue contributes to the national GDP and economic growth, remains beyond the capture of most research even those research that examine gender inequality and economic growth. Research, particularly the empirical one, tends to classify women's economic activities under tow types: paid formal economic activities and unpaid reproductive family labor and neglect their contribution to the informal monetized economic activities. In the following section I introduce some of several examples I found of women run small business and entrepreneurships that count to women's uncaptured contribution to economic growth.

Running a successful entrepreneurship activity (either formal or informal) requires a minimum level of knowledge including the ability to raise and manage money, the ability to be productive, the ability to make entrepreneur friends, the ability to identify strengths and weaknesses, and the ability to connect via social networking (Franck, 2012). Therefore, I begin by shedding light on how those underprivileged women learn and acquaint themselves with entrepreneurship knowledge and skills. Amina, Ola, Nabila, Rasha and Nayera are five examples of illiterate rural women from the three villages in Fayoum who show how unprivileged women 
utilize spontaneous learning from their everyday social interactions to obtain entrepreneurial knowledge and skills and to run informal successful monetized economic activities.

In earlier study Hussein and Mukherjee (2018) found that self-constructed informal networks can serve as learning avenues where underprivileged women can acquire entrepreneurial knowledge and skills through everyday social interactions. Their study suggests that women's everyday social interactions such as conversation, storytelling, and deliberation provide a pedagogical pathway where their self-created social networks serve as avenue for learning. Hussein and Mukherjee (2018) concluded that women spontaneously learn from their social interactions in three different forms as conceptualized by Schugurensky (2000) i.e. selfdirected learning, incidental learning, and tacit learning. In the following section I discuss how women utilize these learning avenues first to acquire entrepreneurship knowledge and skills and then to run successful monetized economic activities. Hussein and Mukherjee highlighted that while most women appeared to be unaware of the learning that happens through their social interactions, they were able to notice and report on it when asked for their reflections. For example, one of the women, Amina, a 25-year-old married woman from Dream Village, said, "I just realized when you asked what I learned from that event, that I incidentally learned a lot from my peers as we spontaneously conversed." In this regard, Lave and Wenger (1991) note that spontaneous conversations represent a form of cognitive apprenticeship where women within a network rotate between the roles of master and apprentice. Women described their interactions within the network as a flat, horizontal (as opposed to vertical, top-down) relationship. These horizontal social interactions foster learning among women because it creates a power dynamic where they can learn and teach each other as both "masters" and "apprentices." These horizontal relationships resemble Lave and Wenger's emphasis on the crucial role of conversation; in other words, the peer-based conversations between women allowed for discussions about their everyday lives and also served as an invitation for dialog on topics like income generating activities and entrepreneurship. This shows how informal network is not only serving as a learning avenue for those illiterate women but also as a meeting hub where they cam make and maintain friendships — one of the requirements for entrepreneurs. In addition, women explained that engaging in conversation within the network facilitated the evolution of their consciousness, which in turn increased their capacity for constructing meaning out of what they were doing. For 
example, Ola, a 29-year-old woman from Hope village, explained how her social interaction with other women in her social network facilitated her entrepreneurial learning:

One day and while I was meeting with other women in our sardine group [one of women's self-created social networks], we had to decide on what dish we would bring for the next meeting in order to estimate the total cost of the meal and determine the contribution of every woman in the cost. I recommended a dish that I make really well, as all other women say, and there were two other recommendations by two other women, my peers. While we were deliberating which dish to bring next time, the majority said that they wanted my dish-stuffed cabbage. Then women asked me how much each woman should pay for her contribution for the meal. Because I have never calculated how much does it cost to prepare such a meal before, I said I don't know. Some of my peers volunteered to provide rough estimates for the meal, but the rest of the women said that these estimates are inaccurate and far less from the actual cost.

Mona [her peer], who knows a lot because she is educated and finished high school, offered to help me solve this dilemma. She took a piece of paper from her daughter's notebook and a pencil. Because she knows I cannot read and write, she asked me to list all the ingredients I will use to cook this meal. She was so smart; she drew three columns on that paper. In the first column, she asked me to list everything I will buy for the stuffed cabbage meal. So, I told her two big size cabbages, two kilos of rice, two bunches of cilantros, two bunches of dill, and one bunch of parsley. Then she said, "won't you use onion, spices, oil, and butter?", I replied, yes, and I do have them at home already. Then she said, "that's why I drew the second column." In the second column, she asked me to add any other ingredients I may use from my home. In the last column, she asked me to add estimate for the gas I will use on my stove to prepare the stuffed cabbage and the time I will spend to prepare the meal. She summed up the cost of the three columns and divided the result by the fifteen of us. Then she collected the contribution of every woman and handed them to me. For the first time in my life I got paid for my labor and I got to know how to estimate the cost of a meal and most importantly how I even price it.

I didn't only learn from Mona, but I practiced what she taught me. What is important was when we all realized that we can start any business when we came together to reflect on what I did. This process and the encouragement of my peer women inspired me to continue do that for living. And as you can see, I am now selling stuffed cabbage to the workers in the nearby construction site and to my neighbors. I also bring stuffed cabbage here to my peers when they choose it for one of our gatherings, thanks for their support.

Ola's example shows how her incidental learning, as a byproduct of her spontaneous social interactions with peer women in their informal gathering, provided a form of informal learning where women's gathering served as an avenue of learning. Ola's learning about estimating product direct and indirect costs and pricing was unintentional, but conscious, because her learning experience occurred when she did not have any preconceived intention to learn about estimating product cost and pricing, rather, it was suggested by her peers through their 
daily social interactions. After the experience with peers in her sardine group, Ola became aware of and appreciated what she had learned incidentally about estimating product cost, pricing, and run a micro business. Although Ola is illiterate, she was able to practice some entrepreneurship functions as a form of entrepreneurial knowledge and skills. Brown, Collins and Duguid (1989) refer to this form of learning as a process of cognitive apprenticeship and enculturation where learners, like Ola, have the "chance to observe and practice in situ the behavior of members of a culture, people pick up relevant jargon, imitate behavior, and gradually start to act" (emphasis in the original, p. 34). The example also shows a form of monetized economic activity that is neither a formal small business nor an unpaid reproductive family labor that most quantitative research tends to use to examine women's economic activities. It also shows the failure of quantitative methodology to capture such contribution of women's informal entrepreneurship to GDP and economic growth as defined by Samuelson (1975).

Another example of informal learning that took place in one of informal women's selfcreated social gatherings is illustrated by Amira, a 28-year-old married woman with four children from Hope Village. Amira narrates:

If I wouldn't participate in the halaqa [one of women's self-created social networks], we wouldn't get to know each other, and I wouldn't have the chance to go out of the house. I learn too many things from other women... we don't only talk about rearing kids; we talk about everything: cooking, health, makeup, religion, and others. I was always bad in making pastry, until I asked Zainab [her peer] to teach me how she makes cake and other good sweet recipes. I also showed her how to make a curtain at home and how to easy draw and sewing embroidery on the curtains. Now, I make fresh pastry every day at home for my family and some to sell in the grocery store owned by my husband and annexed to our house.

Unlike Ola, Amira's learning experience was: 1) intentional as she was self-directed to learn; 2) purposeful because she had the purpose of learning how to make cake and other sweet recipes before the process began; and, 3) conscious because she was aware that she had wanted to learn. The learning experience of intentionality, purpose, and consciousness also applied to the women that wanted to learn about making curtains at home. Similar to Ola's entrepreneurship, Amira's example shows a form of monetized economic activity that is neither a formal small business nor an unpaid reproductive family labor. It also shows how such contribution of women's informal entrepreneurship contributes to GDP and economic growth as defined by Samuelson (1975) and not captured by quantitative research. 
Nabila, a 29-year-old married woman with three children from Dream village, provides another example of informal learning, yet a significant one-tacit learning.

What I wanted when I first joined the group was to get out of the house and talk to someone and spend good time with my peer women. Later, however, I realized that I am having a lot of positive changes in my characteristic as my husband told me. I know that I was shy and withdrawn woman and my mother in law used to tell me that I am an aggressive person. But I must admit that, it's all about confidence. Before I joined this group, I was lacking confidence and I was never able to communicate my feeling with others. Here we are taking care of each other and we never prejudge our ideas. Being a woman in this society, as you know, is hard. Now I am not only able to communicate with other people and convince them to change their attitudes or behaviors regarding my ideas, but I am also able to understand their feelings and emotions. And you are right, without all of these I wouldn't be able to run my business today or even to start it.

Nabila's new attitude reflects another form of informal learning - tacit learning, or socialization as asserted by Schugurensky (2000). Through the social interactions among women, informal social gathering provides a conduit for social exchange where tacit knowledge is passed from one woman to another (Leonard \& Sensiper, 1998). Social gathering, therefore, is the central platform for sharing tacit knowledge among women (Baron \& Markman, 2003). In addition, tacit knowledge is playing an important role in the development of an innovative entrepreneur. Social gatherings are conducive for entrepreneurship since they enable the creation of such tacit knowledge which, as narrated by Nabila, includes social adaptability, social perception, and social persuasiveness as argued by Baron and Markman. In this way, Nabila's new social adaptability, social perception, and social persuasiveness skills and attitude are tacit knowledge and represent a form of tacit learning because Nabila had no prior intention of acquiring them and she was not aware that she has learned these skills until she was told by her husband (Schugurensky, 2000). In addition, such women's group represents a social network of entrepreneurs that provides them with a rich source of collective inimitable tacit knowledge that enables unprivileged women to extend their boundaries of rationality for new ventures.

Women's informal entrepreneurial learning is not limited to the initial knowledge and skills they acquire through their social interactions within social networks. They also learn from their action particularly when they come together and reflect on their actions. Unlike formal and non-formal education, informal learning through action is frequently invisible and mostly results in tacit knowledge. However, for one of the participants, Rasha, and her groupmates, informal learning was the result of entrepreneurial action. Rasha, a 31-year-old woman from Hope village 
who is married with three children, explained how she and her peers utilized the knowledge and skills they acquired from their everyday experiences and group interactions to start their own business. The following narrative by Rasha shows how an entrepreneurial action is instrumental for further entrepreneurial learning and actions.

When Ola started making stuffed cabbage for the workers in the construction site and later expanded it to her neighbors, she shared with us her experience and challenges she faced in initiating her venture by reflecting on her experience during our gathering. I learned from her story and got the confidence and courage to start my own hairdressing and makeup salon at home. In the beginning, I was doing that occasionally for 2-3 hour during noon time as my husband is away at work. But now, my husband helped me prepare and equip one room of our house for my hair salon and makeup business. I am still learning from my peers here whenever I share my experience with them. I also see how other women are curious to learn about what I did.

From this experience, the women learned how to start and run small and micro business. In addition, reflection on their actions led other women to realize that their everyday lived experiences facilitate the development of an entrepreneurial identity that enables learning about their larger context. Rasha's hairdressing salon represents another example of entrepreneurship, and a form of monetized economic activity that is neither a formal small business nor an unpaid reproductive family labor, though it takes place at home, that contributes to GDP and economic growth.

Women's informal learning is not restricted to entrepreneurial knowledge and skills, much of their learning is about a variety of life skills, or experiences that they either bring to the group or acquire through their interactions with each other. The data suggests that the participants believe that the most powerful learning they experienced through their social interactions was the acquisition of life skills. Some examples of learning about life skills reported by participants are negotiation, critical thinking, problem solving, group deliberation and deliberative decision making. Within their social network, women in this study experienced face-to-face negotiation and deliberation as a regular part of their everyday lives. Such life skills are important for women's competency and are necessary for an entrepreneur to start and run successful small business. Yet, how those underprivileged women raise and manage money as a major requirement for running an entrepreneurship is unknown.

One way that statistic-based research (e.g. SYPE) examines women's small and microenterprise contributions to the economic growth is through the available data of women's 
borrowings from government and formal financing institutions or any other formal money lenders. But women of this study reported that they have other informal source from which they secure the capital needed to start their business. One example is the women's "peer-to-peer banking"-informal rotating savings and credit association.

Nayera organized a 24-month rotating savings and credit association for 25 women and men in her neighborhood of Bright village. Like most rural communities in developing countries, unprivileged women in rural Fayoum organize and run this sort of associations as a form of peerto-peer banking and lending for people in need who cannot afford or do not have collateral. Nayera, a 24-year-old married and mother of four, organized a system through which 25 people pay 100 Egyptian Pounds for a monthly membership. Two young women share one membership, paying 50 Egyptian Pounds each. Nayera volunteers the time and efforts needed to organize this rotating savings and credit association. Although this arrangement may entail some risk if any members are not able to pay their monthly installments, Nayera believes it worth her efforts. First, Nayera reports that she is happy helping people who cannot use conventional banks to obtain credit because they do not have proper legal documentations or collateral. Second, Nayera stated that she is committed to returning favor back to her community because she has received similar support during a time of financial need:

...Yes, I am aware that it has some risk if someone doesn't pay the monthly membership after receiving the full amount in advance. I am vulnerable because I am not able to afford it if they were to fall behind in their payments. But I feel obliged to help them, as they helped me when I was preparing for my gihaz [sets of home furnishings] to get married. I still remember that my neighbors organized a game'ya [rotating saving and credit association] for me to buy a few more things before the wedding. I paid it back in monthly installments until I had my first child...there is always a reason that we all have to come together to help a person in need, whether it be to marry, to start a small business, to have a surgery, or to buy a ticket to travel abroad for work.

Like Nayera, several other women mentioned that they either initiate and organize a rotating saving association or participate in a current one. Nayera mentioned that the current rotating saving association is the third one that she has organized, and that members have been committed to paying their monthly installments on time. According to Nayera, organizing such an event helps her gain more recognition from her family and society and help other people start their own income generating activities. Ekman and Amna's (2012) typology provides insight into understanding Nayera's narrative, as an example of an individual form of both social 
involvement and public engagement in the private domain. The association can also be seen as a collective form of social involvement; but it also provides a service where it is lacking from the public or private industry. Those who join Nayera in the association are responsible for providing the funds and assets for those who are in immediate financial need. This informal form of credit source available for small business is in one hand a form of economic activities that contribute to economic growth as articulated by Kappel and Ishengoma (2006). On the other hand, it shows the gender inequality of economic growth and that women's informal business is yet beyond the capture of quantitative research as argued by Ellis, Manuel and Blackden (2005) and Seguino (2000). Furthermore, Nayera's engagement in public concern of her community represents a form of public participation that is uncaptured by most research that adopts SES as a determinant of public participation.

Finally, the stuffed cabbage by Ola, the fresh pastry by Amira, and the hairdressing salon by Rasha are three examples of informal monetized economic activities run by underprivileged women to generate income to that they use to support their families. These three entrepreneurship activities represent a form of monetized economic activity that is neither a formal small business nor an unpaid reproductive family labor. The three examples show the failure of quantitative methodology to capture such contribution of women's informal entrepreneurship to their national GDP and economic growth though they represent determinants of economic growth as argued by Samuelson (1975). Furthermore, Nayera's peer-to-peer banking represents one of unconventional factors motivating women's informal microentrepreneurship as argued by Franck (2012).

\section{Discussion}

The data and analysis above explain how women's informal self-created social networks work as learning avenues to offer unprivileged women the minimum level of knowledge required to run successful entrepreneurship activity (e.g. the ability to raise and manage money, the ability to be productive, the ability to make entrepreneur friends, the ability to identify strengths and weaknesses, the ability to connect via social networking). The discussion also suggests that these examples of women monetized economic activities are neither formal enterprises nor they are unpaid or reproductive family labor. Yet, these informal monetized economic activities remain 
beyond the capture of most quantitative inquiries. While a growing body of microeconomic empirical evidence and emerging macroeconomic analysis (e.g. Alesina, \& Rodrik, 1994; Boserup, Tan, \& Toulmin, 2013; Ellis, 2007; Ellis, Manuel, \& Blackden, 2005; Seguino, 2000; SYPE, 2015) shows that gender inequality directly and indirectly limits women's contribution to economic growth in developing economies. The data suggests that there are legal, social and administrative barriers faced by women that prevent them from participating more directly in formal economic activity. I found that these challenges that facing women and contribute to the gender disparity in economic development and economic growth in developing economies had not been fully addressed in most research particularly those faced by unprivileged rural women. However, my analysis indicates that men and women both play substantial, albeit different, roles in economic growth in the developing economies. Yet, a significant amount of women's participation in monetized economic activities, business and entrepreneurship is unrecognized and their contribution to economic growth remains invisible. The findings reveal that unprivileged women overcome these legal, social and administrative barriers to obtain entrepreneurship knowledge and skills and to run informal small business that still beyond the capture of most empirical research. Incorporating feminist perspectives in my work, I contribute to the body of work that extends analysis to consider the ways in which the contribution of informal, yet monetized, economic activities by gender can influence short- and long-term macroeconomic outcomes especially in developing economies.

I understand that the difficulties that most quantitative research face in assessing the contribution of women's informal business to the GDP and economic growth stem from the traditional way to examine the income of individuals where it mainly considers individuals who derive their income from formal capital and those who derive their income from formal labor. In the case of women's informal business, the situation gets worth as women's income is hard to be classified under neither formal income from formal labor or from formal capital. From one hand women use informal and unconventional source to get the credit and on the other hand their income is not taxed.

\section{Conclusion}

Women are already a powerful force for growth in developing economies. They are business entrepreneurs and capital owners. Recognizing this fact is the first step to ensuring that 
underprivileged women have fair access to the labor market, and do not face even greater barriers to doing business than men do. This paper considers the relationship between gender and economic growth in developing economies. It highlights the methodological divide in examining the contribution of women's informal monetized economic activities to economic growth. The paper provides evidence on the link between social interactions, learning, and entrepreneurship. Unprivileged women construct how informal learning helps transform them to successful entrepreneurs. The findings of this study indicate the considerable potential for economic growth that exists if developing economies are to unleash the power of women and support their full economic participation in different economic activities within the private sector. Removing the legal, social and administrative barriers that impede women's ability to start business and participate directly in monetized economic activities has significant implications for improving family welfare and national economic growth. Finally, the stuffed cabbage by Ola, the fresh pastry by Amira, and the hairdressing salon by Rasha are few of many successful examples of often-neglected informal monetized economic activities run by underprivileged rural women that remain beyond the capture of most quantitative research and beyond the scope of public policy and the outreach of development programs. 


\section{References}

Abu-Lughod, L. (2010). The active social life of" Muslim women's rights": A plea for ethnography, not polemic, with cases from Egypt and Palestine. Journal of Middle East Women's Studies, 6(1), 1-45.

Acs, Z. J., \& Szerb, L. (2007). Entrepreneurship, economic growth and public policy. Small business economics, 28(2-3), 109-122.

Alesina, A., \& Rodrik, D. (1994). Distributive politics and economic growth. The quarterly journal of economics, 109(2), 465-490.

Baraka, P. E. (2008). Citizenship education in Egyptian public schools: What values to teach and in which administrative and political contexts. Journal of Education for International development, 3(3), 1-18.

Baron, R. A., \& Markman, G. D. (2003). Beyond social capital: The role of entrepreneurs' social competence in their financial success. Journal of Business Venturing, 18(1), 41-60.

Baum, M. A., \& Lake, D. A. (2003). The political economy of growth: democracy and human capital. American Journal of Political Science, 47(2), 333-347.

Boserup, E., Tan, S. F., \& Toulmin, C. (2013). Woman's role in economic development. Routledge.

Brady, H. E., Verba, S., \& Schlozman, K. L. (1995). Beyond SES: A resource model of political participation. American Political Science Review, 89(02), 271-294.

Brown, J. S., Collins, A., \& Duguid, P. (1989). Situated cognition and the culture of learning. Educational Researcher, 18(1), 32-42.

Ciccone, A., \& Jarociński, M. (2010). Determinants of economic growth: will data tell?. American Economic Journal: Macroeconomics, 2(4), 222-46.

Cohen, L., Manion, L., \& Morrison, K. (2000). Research methods in education. New York, NY: Routledge Falmer.

Creswell, J. W., \& Miller, D. L. (2000). Determining validity in qualitative inquiry. Theory into Practice, 39(3), 116-159. 
De Sousa Santos, B. (2006). Globalizations. Theory, Culture \& Society, 23(2-3), 393-399.

Downs, A. (1957). An economic theory of political action in a democracy. The Journal of Political Economy, 65(2), 135-150.

Ellis, A. (2007). Gender and economic growth in Kenya: Unleashing the power of women. World Bank Publications.

Ellis, A., Manuel, C., \& Blackden, M. (2005). Gender and economic growth in Uganda: unleashing the power of women. The World Bank.

Finkel, S. E. (2002). Civic education and the mobilization of political participation in developing democracies. The journal of Politics, 64(04), 994-1020.

Franck, A. K. (2012). Factors motivating women's informal micro-entrepreneurship: Experiences from Penang, Malaysia. International Journal of Gender and Entrepreneurship, 4(1), 65-78.

Hussein, H. and Mukherjee, K. (2018). Social networks, social capital and entrepreneurial learning of marginalized women in the developing world, Journal of International Business Research and Practice (JIBRP).

Kappel, R. T., \& Ishengoma, E. K. (2006). Economic growth and poverty: does formalisation of informal enterprises matter?.

Lake, R. L. D., \& Huckfeldt, R. (1998). Social capital, social networks, and political participation. Political Psychology, 19(3), 567-584.

Lave and Wenger (1991) Situated learning: Legitimate peripheral participation. Cambridge, England: Cambridge University Press

Leonard, D., \& Sensiper, S. (1998). The role of tacit knowledge in group innovation. California Management Review, 40(3), 112-132.

Lincoln, Y. S., \& Guba, E. G. (1985). Naturalistic inquiry. California, CA: Sage Publications.

Livingstone, D. W. (1999). Exploring the icebergs of adult learning: Findings of the first Canadian survey of informal learning practices. The Canadian Journal for the Study of Adult Education, 13(2), 49-77. 
Mohamed, H. (2017). Informal social networks, civic learning, and women's political participation. (Doctoral Dissertation). Retrieved from ProQuest Digital Dissertations.

Samuelson, P. A. (1975). The optimum growth rate for population. International Economic Review, 531-538.

Schugurensky, D. (2000). The forms of informal learning: Towards a conceptualization of the field. New Directions for Adult and Continuing Education, 2008(118), 1-8.

Seguino, S. (2000). Gender inequality and economic growth: A cross-country analysis. World Development, 28(7), 1211-1230.

Sieverding, M. (2012). Gender and generational change in Egypt. (Doctoral dissertation). Retrieved from http://escholarship.org/uc/item/6qv110ps 